
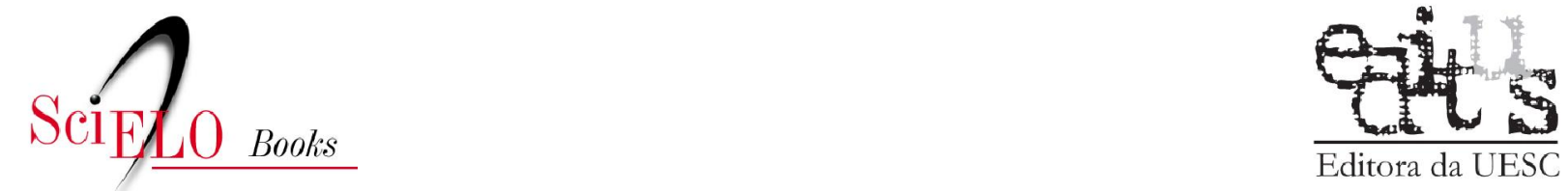

Editora da UESC

\title{
A pesquisa sobre a formação de professores como metaformação
}

\author{
Alba Lúcia Gonçalves
}

\section{SciELO Books / SciELO Livros / SciELO Libros}

GONÇALVES, A. L. A pesquisa sobre a formação de professores como metaformação. In: MORORÓ, L. P., COUTO, M. E. S., and ASSIS, R. A. M., orgs. Notas teórico-metodológicas de pesquisas em educação: concepções e trajetórias [online]. Ilhéus, BA: EDITUS, 2017, pp. 75-100. ISBN: 978-85-7455-493-8. Available from: doi: 10.7476/9788574554938.004. Also available in ePUB from: http://books.scielo.org/id/yjxdq/epub/mororo-9788574554938.epub.

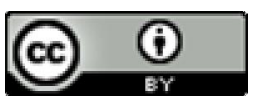

All the contents of this work, except where otherwise noted, is licensed under a Creative Commons Attribution $\underline{4.0 \text { International license. }}$

Todo o conteúdo deste trabalho, exceto quando houver ressalva, é publicado sob a licença Creative Commons Atribição 4.0.

Todo el contenido de esta obra, excepto donde se indique lo contrario, está bajo licencia de la licencia $\underline{\text { Creative }}$ Commons Reconocimento 4.0. 


\section{s. \\ A PESQUISA SOBRE A FORMAÇÁO DE PROFESSORES COMO METAFORMAÇÃO}

Alba Lúcia Gonçalves ${ }^{1}$

"Pesquisar a formação de professores em atuação é pesquisar a minha própria formação.”

Aproximadamente por seis anos, trabalhei em um programa especial para a formação de professores em atuação denominado "Curso de Formação de Professores para a Educação Infantil e Anos Iniciais do Ensino Fundamental - PROAÇÃO”, desenvolvido pela Universidade Estadual de Santa Cruz (UESC). Nesse período, convivi de maneira muito intensa com os alunos e o seu processo formativo e, nessa caminhada, cada vez mais, fui sendo implicada com/e nesse movimento.

$\mathrm{Na}$ minha trajetória como professora formadora, não de futuros docentes, mas sim de professores que já estavam no exercício do trabalho docente, algumas inquietaçóes foram se fazendo presentes no meu dia a dia, a tal ponto que, posso afirmar, minha formação acadêmica também foi se refinando e assumindo um caráter formativo-implicado com a formação do outro e com a minha própria formação. $\mathrm{Na}$ convivência com esses professores-alunos ${ }^{2}$, me percebi, e lançando mão das lembranças, fui refazendo os caminhos trilhados durante a minha

1 Professora Adjunta da Universidade Estadual de Santa Cruz-UESC

2 Nesse texto denominamos de professor-aluno os professores da Educação Básica que assumem o papel de aluno no Curso de Formaçáo Inicial de Professores em Exercício (N.A.). 
própria formação. Nossas histórias, a minha e a deles, apesar de terem começado em épocas diferentes, traziam marcas bem semelhantes. As questôes, as dúvidas e as certezas presentes no trabalho com esses professores foram construídas na transformação da vivência em experiência, pois ao estabelecer uma relação de alteridade com as suas histórias, fui alterando meu olhar a respeito tanto da própria formação como também dos sujeitos da formação, refazendo minhas trilhas formativas.

Imersa nessas reflexóes, decidi investigar a formação de professores. Para isto, tomei como objeto de análise a experiência vivida por esses professores-alunos durante o curso, buscando, através do diálogo, construir uma compreensão mais aprofundada a respeito da formação de professores. Eu faço, portanto, parte do contexto da pesquisa aqui relatada. Tenho e assumo minhas implicaçóes enquanto escolha e vontade política para instituir, por meio dessa pesquisa, o debate acerca da formação, trazendo ao cenário aqueles que viveram a experiência formativa possível no/e durante o curso pesquisado.

Entendo que a interpretação que construí através dessa pesquisa foi mas uma compreensão a respeito do fenômeno estudado, mas afirmo e assumo que essa é uma compreensão. O meu compromisso, portanto, passou a ser o de apresentar um ponto de vista a mais a respeito da temática.

Após decidir o objeto a ser investigado, alguns cuidados precisavam ser tomados. Um deles era o de não cair na "sobreimplicação" que, segundo Macedo (2012), favorece o ativismo e, às vezes, a militância cega e digressiva que no fazer da pesquisa leva para caminhos que significam "não-pesquisa". Busquei, então, cotidianamente, um certo distanciamento, colocando minhas implicaçóes em questão para, assim, chegar à reflexão necessária que possibilitasse a aproximação da essência da pesquisa. Neste sentido, fez-se necessária uma discussão teórica com autores que têm desenvolvido estudos acerca da formação, de um modo geral, e da formação de professores em atuação profissional, de maneira específica, para, então, entender o lugar dessas pesquisas e suas relaçóes com a produção do conhecimento a respeito dos professores da Educação Básica. 
Como centrei a pesquisa empírica no entendimento do lugar das experiências individuais e coletivas dos sujeitos nos processos formativos vivenciados no PROAÇÃO, senti que precisava explicitar melhor os conceitos de "formação" e de "experiência".

Para delimitar o conceito de experiência, inicialmente tomei Larrosa (2002) e Walter Benjamin (1994) como referenciais. O primeiro autor tornou-se importante para a pesquisa, pois afirma ser a experiência aquilo que nos passa, o que nos acontece, o que nos toca, não o que se passa, náo o que acontece, ou o que se toca. Da mesma forma, Walter Benjamin (1994) observa a pobreza de experiências que caracteriza o nosso mundo, onde se passaram e passam tantas coisas, sendo elas cada vez mais raras.

A partir dessas perspectivas, experiência e informaçáo se distinguem como coisas diferentes e, às vezes, até mesmo opostas. $\mathrm{O}$ excesso de informaçáo, por exemplo, pode acabar por náo deixar lugar para a experiência, tornando-se, portanto, quase que o contrário da experiência, quase uma antiexperiência. Por outro lado, a experiência, para tornar-se um elemento importante tanto na formação pessoal quanto na profissional do sujeito, precisa ser refletida, tensionada, explicitada, e a falta de informação pode comprometer esse debate e essa reflexão. O desafio é trazer informaçôes que se constituam dispositivos necessários ao debate da/e na experiência para que essa seja formativa.

Sob essa ótica, a formação terá que ser crítica/intercrítica, pois, nesse movimento formativo, a crítica não se reduz a uma postura que busca enxergar as "impurezas" de tal realidade, para, a partir daí, estabelecer verdades a seu respeito. Uma postura formativa será sempre um movimento intercrítico, conforme já explicitado por Macedo (2010), que busca se aproximar das compreensões que foram ou são possíveis de serem construídas naquele contexto, espaço, cenário e, neste movimento interpretativo, vâo-se construindo as compreensóes necessárias e possíveis. No caso específico da formação de professores, terão que ser asseguradas as condiçóes necessárias para que eles sejam capazes de fazer a crítica numa postura intercrítica, isto é, se 
responsabilizando pelo seu próprio processo construtivo em relação ao outro, ao saber, à formação. A revalorização e a redescoberta do potencial formativo das situaçôes de trabalho podem, assim, propiciar tanto a produção de estratégias, dispositivos e práticas de formação que valorizem fortemente a aprendizagem, pela via experiencial, quanto o entendimento do papel central de cada sujeito num processo de autoconstrução como pessoa e como profissional.

A pesquisa realizada, portanto, náo se constituiu em uma comparação entre o anunciado, proposto pelo curso, e o vivido, mas sim em um estudo interpretativo das açóes tomadas pelos professores-alunos para instituir os seus processos formativos no referido curso. Sendo assim, teve como movimentos centrais: 1) a compreensão, por parte dos professores-alunos do PROAÇÃO, das aprendizagens adquiridas por eles no curso; 2) a relação dessas aprendizagens com o processo formativo vivido por esses atores sociais no curso; 3) o lugar ocupado por suas experiências individuais e coletivas nos "atos de currículo" (MACEDO,2013) do curso, ficando clara a necessidade de aproximação da experiência desses atores para entender suas aprendizagens.

A partir desses movimentos, fez-se necessário o levantamento de algumas questóes: as experiências são, realmente, contempladas no currículo do curso? Qual tem sido o debate formativo acerca dessas experiências? Quais são os debates acerca do mundo do trabalho desses sujeitos e seus espaços formativos nas itinerâncias de suas vidas profissionais? Movida por essas inquietaçóes, senti a necessidade de compreender a proposta do curso, no sentido de identificar as possibilidades de gerar, para esses professores(as) que estão na posição de alunos(as), e, portanto, inseridos no mundo do trabalho, novas necessidades de aprendizagens.

Outras questóes que me inquietaram dizem respeito à compreensão que esses professores-alunos tinham das aprendizagens adquiridas por eles no curso, e que relação estabeleciam entre elas e o trabalho pedagógico desenvolvido, tanto na sala de aula como na escola. Como professora do curso já havia observado que o mesmo 
provocava algumas mudanças nos professores-alunos. Essas mudanças, tal como foram explicitadas na tese de doutorado de Mororó (2005), consistiram em melhorar a autoestima do sujeito, sua relaçấo com o estudo e em transformaçóes na forma de conduçáo do ensino. Entretanto, que outras mudanças foram provocadas?

Nesse esforço de compreensão do vivido, um movimento relevante foi o da reflexão refinada e crítica por parte desses professores-alunos, tanto no nível individual quanto no coletivo, sobre a sua formação. Entendendo-a como "um acontecimento encarnado, implicado e relevante" (MACEDO, 2010, p. 30), desde o início da pesquisa uma necessidade imposta foi a de captar como os professores-alunos avaliavam a sua própria formação (metaformação) ${ }^{3}$ e como relacionavam sua formação com o mundo do trabalho docente (entrecurrículo $)^{4}$. Meu desafio, agora, como pesquisadora, era o de me aproximar da experiência desses atores para entender suas aprendizagens através da escuta sensível de questóes que, ao longo da pesquisa, foram se apresentando como significativas para o seu processo formativo.

Outra decisão inevitável foi em relação à metodologia de pesquisa a ser utilizada. Dentre os vários caminhos possíveis, a opção se deu a partir da própria concepção de pesquisa, que, nesse caso, não poderia considerar os atores sociais como meros fornecedores de informaçōes e sim como protagonistas do vivido e realizado em seus processos formativos, sendo, portanto, coautores, os instituintes ordinários de suas realidades (MACEDO, 2012). Isso fez com que, desde o início da pesquisa, apresentasse as minhas inquietaçóes ao grupo e, conjuntamente, definisse o olhar a respeito do caminho a seguir.

A etnometodologia se constituiu, então, como metodologia eleita para o desenvolvimento da pesquisa. Isso por ser ela uma teoria voltada para compreensão da ordem social a partir da

3 Compreensão que os atores sociais vão construindo em seus percursos a respeito da sua própria formação (N.A.).

4 São conhecimentos tidos como não oficiais, institucionais, mas, que estão presentes a partir das itinerâncias de formação descritos pelos sujeitos em formação (N.A.). 
valorização das açóes cotidianas, coerente, portanto, com o meu desejo de compreender o processo de formação desses protagonistas por meio da escuta sensível de seus relatos.

Desta forma, o trabalho com entrevistas individuais se constituiu em um espaço narrativo de suas percepçôes e implicações, e o grupo focal em lócus como o espaço de debate acerca dessas percepçôes. Pretendo, assim, chegar a uma reflexão coletiva acerca do vivido e de suas marcas individuais e coletivas na formação desses homens e mulheres, professores da Educação Básica.

Como o objetivo desse texto é o de favorecer a compreensão de como se deu a organização desse estudo, isto é, o próprio desenvolvimento da pesquisa, sua metodologia e os processos de coleta de informaçóes realizados, bem como os procedimentos adotados na organização e análise dessas informaçôes, não detalharemos os resultados da pesquisa, mas sim o seu processo de construção.

\section{Ciência e pesquisa: minhas opçóes}

As conversas mexeram comigo, comecei a reviver alguns momentos e perceber como eles foram importantes pra mim; o engraçado era que eu náo achava que você estivesse me fazendo perguntas para depois analisar minhas respostas. Era um раро... um diálogo entre eu, você e o curso. Depois vieram as reunióes em grupo. Encontrar meus colegas e reviver juntos aqueles momentos foi demais. Eu no início me perguntava sobre o que vamos conversar, já falei tudo. Mas, a cada reunião, eu saía em parafuso. Continuava pensando nas discussôes, nas falas das colegas; elas traziam informações que eu nunca tinha parado para pensar. Isso foi forte (Professora-aluna Magda).

Buscando delimitar a minha postura teórico-metodológica de investigação, parti de alguns pressupostos sobre os quais enxerguei 
a pesquisa qualitativa ancorada nos princípios da etnometodologia como sendo a postura teórica que melhor se adequa ao objeto de estudo que investigo, pois, esse, ao mesmo tempo em que está inserido em uma realidade histórica e multirreferenciada, também consiste em "uma interpretação singular" dessa mesma realidade, deixando à mostra essa natureza multirreferenciada da realidade e as suas contradiçóes.

Apoiada nos estudos de Macedo (2006), concordo com a sua defesa da etnometodologia enquanto orientação teórica fundante. Desta forma, minha opção pela etnometodologia se deu por acreditar que este procedimento nos possibilitaria uma melhor compreensão do processo formativo dos professores-alunos, haja vista o trabalho voltado para os microcontextos de formação vividos por eles no interior do curso, por meio das aulas dos professores, das reuniôes de estudos, das atividades de formação em serviço, entre outras vivências ocorridas no cotidiano dos estudos, como as conversas com os autores estudados, com os docentes e, entre eles, como forma de apreender o que se passa nos "entrelugares" do dia a dia da formação desses professores-alunos.

Estudos apontam que a teoria da etnometodologia surgiu como uma corrente da sociologia americana nos anos 1960, nos Estados Unidos, e, posteriormente, difundiu-se pela Europa, particularmente nas universidades inglesas e alemãs. A obra de Harold Garfinkel, Stuties in Ethnomethodolgy (1967), é considerada o marco inicial desta corrente. Essa publicação provocou discussóes e reviravoltas acadêmicas tanto na América do Norte como na Europa, pois rompeu efetivamente com a sociologia tradicional. Neste texto, o autor revela que, ao deixar a Universidade de Ohio em 1954, havia trabalhado na análise das fitas gravadas durante as deliberaçóes de um tribunal do júri, e que, dessa forma, ele pôde descrever os procedimentos adotados pelos jurados em seus etnométodos. No dizer de Macedo (2009), estas maneiras de ser, as formas e os jeitos como os atores sociais compreendem, mobilizam e implementam suas ações, interpretando-as e descrevendo-as para todos os fins práticos, é que fundamentam o estudo da etnometodologia. 
Posso afirmar que a etnometodologia se fundamenta no estudo do raciocínio prático do cotidiano, buscando evidências para reconstruir uma explicação da realidade observada. $\mathrm{Na}$ concepção de Coulon (1995, p. 15), "trata-se da análise das maneiras habituais de proceder mobilizadas pelos atores sociais comuns a fim de realizar suas ações habituais". Portanto, o objetivo da etnometodologia é a busca empírica dos métodos que constituem o conjunto dos etnométodos que os indivíduos utilizam para comunicar-se, tomar decisōes, raciocinar, isto é, o conjunto de procedimentos que são usados para produzir e reconhecer o seu mundo, de forma que se saiba como eles constroem as suas atividades no cotidiano.

Os trabalhos de Macedo (2009), Coulon (1995) e Garfinkel (2005) me permitiram entender que a etnometodologia náo pode ser confundida exclusivamente com uma metodologia ou mesmo com um método de pesquisa. Ela se destaca por ser uma teoria social voltada para o interesse da compreensão da ordem social, a partir da valorização das açóes cotidianas dos atores envolvidos nos processos sociais. Daí poder falar de pesquisa inspirada na etnometodologia. Neste sentido, ela é uma perspectiva de pesquisa, uma nova postura intelectual (COULON, 1995, p. 7).

Nesta direçâo, a valorização do ator social tem uma relevância fundamental dentro da etnometodologia. Garfinkel (2005) atende às necessidades de muitos pesquisadores que não se interessam pelas teorias positivistas, que dão ênfase às pesquisas quantitativas e aos conhecimentos científicos, desprezando todo conhecimento popular. Macedo (2009, p. 68) afirma que, para Garfinkel, "[...] o ator social não é um idiota cultural". Ele tem, portanto, seus valores e conhecimentos que não podem e nem devem ser desprezados pelas ciências. Santos (2008, p. 111) sustenta essa nossa posição quando diz que "é fundamental transformar ausências em presenças reconhecendo nas práticas cotidianas inovaçôes emancipatórias".

Macedo (2009) assinala que etnometodologia e educação fundem-se num encontro tão seminal quanto urgente, em face da inércia compreensiva fundada pelas análises "duras". Toman- 
do o viés interpretacionista, os etnometodólogos interessados no fenômeno da Educação buscam o traching dos etnométodos pedagógicos, isto é, uma pista através da qual tentam compreender uma situação dada, bem como praticam afilature, ou seja, o esforço de penetrar compreensivamente no ponto de vista do ator pedagógico, nas suas definiçóes das situações, tendo como orientação forte o fato de que a construção do mundo social pelos membros é metódica, apoia-se em recursos culturais partilhados, que permitem não somente o construir, mas, também, o reconhecer.

$\mathrm{O}$ autor esclarece que o objetivo da etnometodologia é a busca empírica dos métodos ou procedimentos, entendidos como as realizaçóes práticas que os indivíduos utilizam para dar sentido e, ao mesmo tempo, construir suas açóes, seus etnométodos, produzindo, assim, os fatos sociais. Também acrescenta que foi a partir da introdução da etnometodologia no âmbito das pesquisas que se ampliaram os pensamentos sociais e se inverteram as posiçóes na busca pela compreensão do objeto de estudo. Este posicionamento possibilita a interlocução com a abordagem multirreferencial, a qual admite a busca pela compreensão do objeto-pesquisa por meio da observação, da escuta, do entendimento, da procura, da implicação, da incorporação do sujeito e da história do sujeito com a realidade investigada.

Correia (2006) corrobora com essa ideia afirmando que, nesse aspecto, reside uma inter-relação da concepção teórica da etnometodologia com a abordagem multirreferencial, já que ambas procuram ultrapassar os limites de uma disciplina única, de uma teoria, e buscam, no pensar diferente das disciplinas, dos procedimentos, das teorias, das concepçôes, a compreensão do objeto estudado. É uma ampliação de olhares epistemológicos.

Essa ampliação de olhares para a leitura do objeto, proposta por Ardoino (1998), pode se constituir na articulação e no diálogo entre a multirreferencialidade e a etnometodologia. Segundo Coulan (1995), as duas noçóes podem dialogar na prática concreta da pesquisa e não apenas em debates teóricos, como se poderia pensar inicialmente. 
Minha escolha pela multirreferencialidade se deu pelo fato desta abordagem utilizar a "interpretação/compreensão/explicação, rompendo com a expectativa construída ao longo da história das ciências macrossociais, da explicaçáo assentada na análise lapidante" (MACEDO, 1999, p. 58). Meu movimento foi sempre na direção da compreensão do processo formativo dos professores-alunos no curso de formação de professores em atuação. Essa compreensão foi pela escuta sensível desses atores sociais e, sendo assim, eles são coautores desta pesquisa e não apenas informantes.

Minha postura ética foi no sentido de promover, por meio da pesquisa, uma discussão implicada acerca da formação inicial de professores em exercício. Um dos primeiros desafios foi romper com julgamentos já estabelecidos entre o bem e o mal, o certo e o errado, com aqueles que acreditam e se apaixonam por esses tipos de cursos e com aqueles que rejeitam totalmente essa modalidade de formação de professores. Sendo assim, não foi minha intenção ficar presa a apenas uma teoria, pois acredito que nenhuma, isoladamente, poderia dar conta de compreender o objeto estudado, sendo necessário pluralizar os olhares epistemológicos.

Nessa perspectiva, o encontro com a multirreferencialidade foi fundante na construção desse trabalho. Macedo (2000) foi o primeiro brasileiro que uniu a etnometodologia e a abordagem multirreferencial na construção e apresentação de sua tese "A etnopesquisa crítica e multirreferencial nas ciências humanas e na educação". Em seu trabalho, procurou organizar e sistematizar a pesquisa fazendo o papel de sujeito que observa e sujeito observado. O movimento vivido por esse pesquisador se deu ao procurar romper com as concepçóes tradicionais de se fazer pesquisa, as quais enaltecem o método, a objetividade, a quantificação e a obsessão pelo medir, buscando expandir o presente no sentido de valorizar a inesgotável experiência social no mundo de hoje em nossas escolas.

O autor ainda evidencia a construçáo do sentido do objeto estudado, levando em conta a subjetividade. Há, logicamente, um esforço para examinar o sentido do lugar ocupado pelo 
prático pesquisador, como assinala, buscando compreender suas ações e seus significados. As posiçóes teóricas assumidas trazem as discussóes fazendo um entrelaçamento das correntes adotadas por Coulan (1995), Ardoino (1998) e seus colaboradores.

\begin{abstract}
Ele nos esclarece que o conceito de multirreferencialidade é inicialmente forjado pelo trabalho de reflexão crítica sobre a pretensão purista de uma única ciência da educaçáo. Foi com Jacques Ardoino, no seio dos debates do Departamento de Ciências da Educação da Universidade de Paris Vincennes à Saint-Denis, inspirado nos movimentos emancipacionistas dessa Universidade desde a sua fundação a partir dos movimentos de maio de 1968 em Paris, que a perspectiva multirreferencial vai afirmar a emergência impura, paradoxal e mestiça das ciências da educação (MACEDO, 1999, p. 123, grifos do autor).
\end{abstract}

A discussão da abordagem multirreferencial no âmbito da educação vem romper com pressupostos teóricos positivistas a respeito dessa área. De acordo com Ardoino (1998), o surgimento dessa abordagem no contexto educacional está ligado ao reconhecimento da complexidade e da heterogeneidade no processo educativo. Os estudos que tenho realizado acerca dessa abordagem mostram que ela está aberta à complexidade da realidade e à interiorização significante do sujeito observador, e não é fechada em si, mas está aberta às contribuiçóes advindas das pesquisas e dos estudos, outra característica próxima da etnometodologia.

Outra inspiração na compreensão da multirreferencialidade veio de Morin (2000, p. 48), quando afirmou que "só podemos entrar na problemática da complexidade se entrarmos na da simplicidade, porque a simplicidade não é tão simples quanto parece". Pensar, portanto, a formação de professores em atuação pode parecer simples para quem tem um olhar simplificador, mas, sei, ou passei a saber durante o desenvolvimento desta pesquisa, que construir uma compreensão acerca da formação dos atores sociais participantes do curso foi um ato complexo e difícil. 
Entendo que a abordagem multirreferencial assume a hipótese da complexidade, uma vez que propóe uma leitura plural de seus objetos, numa perspectiva teórica e prática, sob os diferentes pontos de vista, reconhecendo a heterogeneidade no campo das Ciências Humanas e das Ciências da Sociedade.

A opção pela multirreferencialidade deu-se por entender que a discussão por ela implementada sobre a heterogeneidade como o cerne da construçáo do conhecimento, constitui-se em um caminho possível para a compreensão do processo formativo de homens e mulheres que, implicados na sua própria formação, foram à universidade fazer um curso de graduação e produziram conhecimento a respeito de si e do seu trabalho.

A ampliação de olhares para a leitura desse objeto, a formaçáo de professores, só foi possível por meio da articulação e do diálogo entre a multirreferencialidade e a etnometodologia.

Nesse processo, compreendi que tanto os resultados como a minha interpretação a respeito deles não podem ser considerados como únicos. $\mathrm{O}$ processo investigativo vivenciado por mim estabeleceu uma relação entre sujeitos, uma relação dialógica, na qual o pesquisador e os pesquisados formaram partes integrantes da pesquisa e nela se ressignificaram e alcançaram a compreensão possível (MACEDO, 2009).

Tal pensamento se consolidou pelo fato de os atores sociais participantes dessa pesquisa não terem sido considerados idiotas culturais e sim aprendentes e ensinantes, em um ambiente formativo. Minha intenção não foi vê-los como meros informantes, e sim como autores que se autorizam, nas narrativas, a expressar sua experiência formativa vivida no referido curso (MACEDO, 2009).

Em relação ao tratamento dado às narrativas, meu papel foi interpretar as diversas falas desses atores sociais e produzir este texto como registro científico do conhecimento construído e expresso a respeito da sua formação e dessa formação no curso do qual participaram na condição de aluno. Minha vontade foi assumir o papel do etnógrafo de campo (CLIFFORD, 1998), ou seja, aquele que descreve e, também, vivencia a cultura do outro. 


\section{Os dispositivos de coleta, organizaçáo e análise de informaçóes}

A coleta de informaçóes constituiu-se no resultado da minha aproximação com esses atores sociais, no esforço de compreender os etnométodos construídos e produzidos por eles durante a realizaçáo do curso. Neste sentido, me apropriar do conceito de instrumentos como dispositivos provocadores do diálogo tornou-se essencial para a compreensão acerca da formação desses professores-alunos.

Sendo assim, utilizo como dispositivo para coleta de informaçôes o questionário, a entrevista e o grupo focal. Essas escolhas foram realizadas pelo fato de possibilitarem uma escuta sensível das histórias e itinerâncias formativas dos diversos atores sociais participantes da pesquisa. Dessa forma, no esforço interpretativo, pude compreender, de forma contextual e relacional, os limites e as possibilidades do curso de formação de professores, ofertado pela Universidade Estadual de Santa Cruz, ter-se constituído em um espaço formativo para os educadores da educação básica que se dirigiram a essa instituição na crença de que ali se tornariam melhores professores (as).

As informaçóes dos atores sociais foram coletadas via subjetividade, através da observaçáo. Entendo que mesmo não tendo sido um dispositivo eleito, ela esteve presente em toda a minha trajetória no campo, por meio do olhar atento aos gestos, falas, movimentos corporais e outros que expressavam as açóes e as reaçôes dos atores sociais.

A pesquisa teve início com a aplicação do questionário. No começo da pesquisa não era minha intenção utilizar esse dispositivo, mas, em função do curso estar sendo finalizado e da minha necessidade de obter algumas informaçôes que me ajudariam na organizaçáo da pesquisa, o apliquei. Elaborei esse instrumento com questôes abertas e fechadas que buscavam dois tipos de informaçôes: os dados pessoais e os dados profissionais. Neste mesmo questionário, os atores sociais expressaram seu desejo e disponibilidade para participar da pesquisa na fase das entrevistas. Dos 153 professores-alunos, 115 responderam ao questionário, correspondendo a 
$75 \%$ de devolução. Essas informações foram organizadas e me permitiram ter um perfil inicial acerca dos atores sociais, além de ajudar a selecionar os que participariam da seguinte etapa da pesquisa.

A definição da entrevista como outra etapa de coleta de dados se deu em razão desse recurso possibilitar uma conversa individual com cada ator social, participante da pesquisa, permitindo uma maior proximidade entre pesquisador e ator social. Isso me possibilitou rever conceitos já estabelecidos. Esta interação foi importante, pois esses atores sociais possuíam um conhecimento experiencial acerca do fenômeno estudado, ou seja, a formação de professores em exercício. Tal fato promoveu uma revisão e até mesmo a alteraçáo de alguns conceitos já definidos. Nas falas e entrefalas que moveram nosso diálogo foi possível esse movimento.

Durante a realização das entrevistas, busquei sempre reconstruir os processos interativos que produziram a construção dos diversos pontos de vista desses sujeitos a respeito do processo formativo vivido por eles no curso. Participaram das entrevistas quinze professores-alunos.

Previ dois encontros com cada um dos entrevistados: no primeiro, buscaria conhecer um pouco de sua história de vida, de sua trajetória familiar e profissional e do seu tempo de formação na UESC. No segundo, teria uma conversa acerca do curso propriamente dito. De posse do roteiro de entrevista, e com essa preocupação, organizei minha ida a campo.

Passei a fazer os contatos por e-mail e telefone, convidando os professores-alunos para nossas conversas. Como eram quinze professores da rede municipal, mas que trabalhavam em instituiçôes diferentes, minha preocupação era que cada participante indicasse o local mais apropriado para à realização das entrevistas. A consulta foi feita e, no final, utilizei os espaços das unidades escolares, da Casa do Educador e a residência de duas entrevistadas.

Durante a realização das entrevistas, foi possível observar e conviver com o cuidado, a receptividade, a cordialidade e a alegria de cada ator social. Eles estavam abertos e confiantes. Esse compor- 
tamento foi imprescindível para criar uma ambiência descontraída e, ao mesmo tempo, náo perder o rigor necessário nessa etapa da pesquisa (MACEDO, 2009).

Os encontros entre uma sessão e outra da entrevista aconteciam em um intervalo de três dias, o que alterava a rotina de trabalho desses professores, mas, ao mesmo tempo, garantia tempo para que "refrescassem" suas memórias em relação à materialidade do curso.

As professoras e os professores participantes da pesquisa optaram por ser identificados no corpo do texto por seus nomes verdadeiros, fato que, para o estudo, foi muito importante, pois acreditamos que "o sujeito encarnado" "participa de uma dinâmica criativa de si mesmo e do mundo com que ele está em permanente intercâmbio" (NAJMANOVICH, 2001, p. 23). Ao trabalhar com o princípio de que o outro é um sujeito ativo, participante da ação, o seu nome marca a sua participaçáo enquanto ser social e profissional, com uma história própria. Vale a pena destacar que, ao questionar a possibilidade de utilizar seus nomes verídicos, uma das professoras me disse que não via motivos para não ser identificada, já que assume o que fala e faz - é um sujeito de seu tempo.

As entrevistas foram transcritas e me concentrei na leitura das informaçóes para encontrar nas narrativas, os aspectos anunciadores do movimento formativo vivido no curso. Na leitura cuidadosa, ao mesmo tempo em que buscava pontos comuns nas falas, também procurava os pontos singulares. Esse movimento me permitiu encontrar conflitos vividos no desenvolvimento do curso, os quais se tornaram temas para o debate no grupo focal.

Para a realização do grupo focal, realizei uma primeira reunião com todos os participantes das entrevistas individuais para tomar as decisôes coletivamente a respeito da etapa seguinte da pesquisa.

No dia marcado, compareceram dez professores, definindo, assim, a formação do grupo. O meu objetivo com a realização do grupo focal era o de aprofundar o debate para compreender o processo formativo desses professores, ex-alunos do curso, através de conversas a respeito de quatro temáticas que se evidenciaram nas 
entrevistas individuais, a saber: a relação teoria e prática na formação de professores em atuação, a relação de pertencimento junto à instituição formadora, o lugar das experiências pessoais e profissionais no curso e a relação estabelecida entre formação e a atividade profissional exercida agora.

Neste sentido, como afirma Gatti (2005), procurei criar as condiçóes para que cada participante do grupo se situasse, explicitasse seu ponto de vista, fizesse as análises que julgasse necessárias e abrisse perspectivas diante da temática sobre a qual estávamos conversando coletivamente. Enfim, meu desafio foi criar condiçóes para que o debate, mais geral, a respeito da formação de professores acontecesse, e que nesse cenário os participantes do grupo pudessem, realmente, emitir seu juízo de valor a respeito das questóes anunciadas nas entrevistas individuais sobre a participação deles no curso.

No primeiro encontro, as pessoas foram chegando e conversando entre si, tentando saber como tinham sido as entrevistas individuais e quais as expectativas para a continuidade da pesquisa. Todos e todas estavam empolgados e querendo saber das novidades. Após a recepção individual, sentamos à mesa e começamos nossa reunião. Expliquei que o encontro tinha dois objetivos, um era construirmos os próximos passos da pesquisa e organizar a agenda de encontros, e o segundo era entregar a cada um a transcrição das entrevistas individuais para que eles fizessem a leitura e, se assim desejassem, acrescentassem ou retirarssem alguma informação dada nas entrevistas. Neste momento, entreguei as cópias das transcrições das entrevistas para cada ator social que realizou a leitura imediatamente. Como estavam muito animados com a leitura, parei a nossa conversa para deixar que ela acontecesse. Este momento foi muito rico, pois na medida em que realizavam as leituras, eles iam fazendo comentários e acrescentando mais informaçôes.

Após esse momento, começamos o planejamento da próxima etapa da pesquisa. Fiz uma breve apresentação a respeito do grupo focal, esclareci as funçóes das pessoas que trabalhariam nas reunióes, ou seja, dos membros do grupo, o animador, o narrador (que ao longo do debate faria as anotaçóes) e, por fim, a assistente, que 
filmaria os encontros. Outra definiçáo foi a respeito da periodicidade das reuniôes. Ficaram agendados encontros semanais, às quartas-feiras, no final da tarde. Todos os presentes preferiram manter o local em que estávamos para os próximos encontros. Em relaçáo ao tempo de duração das reunióes, o grupo concordou que cada encontro aconteceria em uma hora e trinta minutos, mais ou menos. As reunióes do grupo focal seriam filmadas, e após a conclusão dos encontros, entregaria a mídia com a filmagem para que assistissem e acompanhassem a fidedignidade das transcriçôes.

O ambiente escolhido para as reunióes foi organizado com bastante cuidado. Havia uma mesa grande com cadeiras suficientes para todos(as); cada um tinha um crachá com seu nome bem visível, papel e lápis para quem quisesse fazer anotaçôes. Foram providenciados café, água, suco e biscoitos para o lanche. Ao todo, foram realizadas quatro reunióes com os participantes do grupo focal, tempo considerado suficiente para que as questóes levantadas se esgotassem. No final da última reunião, tomamos decisōes a respeito da continuidade da pesquisa, e nosso acordo foi o de apresentar minhas análises para o grupo e promover um debate final a respeito dos resultados.

As reunióes começavam com a apresentação, pelo animador, da questão a ser debatida. A primeira questão foi: "Qual é o lugar da teoria na formação de professores em atuaçáo?" Pontuei que este tema foi eleito por ter surgido a partir das entrevistas individuais. Após a pergunta, percebi que eles pararam um pouco, como se estivessem respirando fundo e buscando as lembranças do curso para se situarem. Em seguida, uma das professoras começou a falar. No início estavam meio constrangidos e se comportavam como se estivessem falando para mim, mas, aos poucos, as tensóes foram cedendo lugar à descontraçáo e o debate aconteceu com certa tranquilidade. $\mathrm{O}$ tempo passou, náo percebemos. No final da reunião, eles/elas falaram sobre suas impressóes iniciais, o medo, a vergonha e a incerteza; mas na medida em que o debate acontecia iam sendo tomados (as) pela temática e se afastaram desses sentimentos. 
$\mathrm{Na}$ segunda reuniáo, o debate foi a respeito do sentimento de pertencimento deles com relação à universidade. A questấo norteadora foi: "Ter entrado para a Universidade por meio do PROAÇÃO fez com que você se sentisse pertencente ao quadro de alunos da universidade?" Eles narraram seus sentimentos, discordaram do posicionamento uns dos outros e foram apresentando seus argumentos, foram conversando naturalmente e, assim, o debate fluiu.

$\mathrm{Na}$ terceira reunião, a temática discutida foi a respeito da experiência. Nas entrevistas individuais, todos afirmaram que a experiência profissional havia entrado no curso, mas eles não tinham muita clareza a respeito do lugar que ela tinha ocupado na formaçáo. As leituras das entrevistas apontaram a necessidade de uma discussão mais profunda a respeito do próprio conceito de experiência, para entâo compreendermos o seu lugar na formaçáo de professores em atuação. A conversa se deu a partir da seguinte questão: "Por que a experiência de vocês entrou para o currículo do curso?"

$\mathrm{Na}$ quarta e última reunião, com a presença reduzida dos professores-alunos, nossa conversa foi a respeito de como se sentiam naquele dia, tanto nas atividades profissionais quanto na vida pessoal; eu queria compreender o impacto da formação na vida desses atores sociais. A questão foi: "O que vocês estão fazendo hoje e quais as implicaçôes de vocês nesse fazer?"

As informaçōes foram organizadas durante a realização da pesquisa em três tempos: o do questionário, o das entrevistas e o do grupo focal. As informaçóes coletadas através do questionário foram agrupadas em três temas: dados pessoais, dados profissionais e continuidade da pesquisa. Esse perfil dos atores sociais foi complementado com as entrevistas individuais. Em seguida, organizei as informações contidas nas entrevistas. Como as narrativas eram muito amplas, fiz o exercício de separá-las e agrupá-las por temática. Esse movimento só foi possível após várias e exaustivas leituras. Foi com elas que enxerguei as temáticas maiores que continham as narrativas. Para chegar às temáticas, primeiramente reafirmei minha questão de pesquisa e os objetivos; a partir daí fui realizando 
as leituras e, ao mesmo tempo, destacando as falas mais presentes nos diálogos. Como resultado, encontrei as categorias: o sujeito da experiência, as condiçôes objetivas da formação de professores em atuação e o curso como espaço formativo.

Após a organização dessas informações, foi possível voltar à literatura acerca da formação de professores em atuação e, então, organizar a realização do grupo focal. As informaçôes coletadas nas reunióes do grupo me permitiram acompanhar o que os professores-alunos foram construindo a respeito da sua formação, e, também, definir as categorias empíricas de análise. Cabe ressaltar que minha pretensão era a de construir a compreensão do processo de formação vivido pelo grupo e, sendo assim, utilizei as narrativas como espaços de descrição das suas vivências no curso, pois acredito que esses relatos constituem-se, até certo ponto, na própria história desses sujeitos e da sua formação. Neste sentido, meu foco não foi o de chegar a resultados ou a compreensóes já fixadas a respeito da formação de professores em atuação, e sim trazer à tona, por meio da voz desses atores, uma nova compreensão desse processo.

Macedo $(2009,2006)$ afirma que o movimento de análise começa com o exame atento e extremamente detalhado das informações coletadas no campo de pesquisa. Essa tarefa foi exercida com rigor. As falas dos professores-alunos foram registradas por meio de gravador de áudio e das filmagens que foram transcritas na íntegra, e em seguida entregues a esses atores sociais para que as conferissem. Após sua autorização, realizei uma leitura exaustiva dessas informaçóes e fiz o confronto entre elas, a questão da pesquisa e seus objetivos. Neste movimento, ao mesmo tempo indagava sobre a importância das informaçóes coletadas e separava as que considerava relevantes para a análise. Selecionei, assim, as partes da descrição consideradas essenciais para a compreensão do processo formativo vivido pelos atores sociais no curso.

Enxerguei como necessária uma busca histórica a respeito da formação de professores. Precisava situar, historicamente, o momento em que surge a formação de professores em atuação, no 
Brasil, e como esses elementos apresentados por esses atores sociais se constituem demandas para se pensar a formação de professores em atuação. Outra necessidade foi compreender como se estabeleceram as condiçóes objetivas para que eles participassem do curso. Esses estudos me permitiram entrar no contexto para construir uma "triangulação ampliada" (MACEDO, 2009) necessária, a princípio, à compreensão e discussão das informaçôes. Após realização desses estudos, foi possível encontrar, nessas unidades de significação, as chamadas categorias empíricas e realizar a interpretação compreensiva desse objeto de pesquisa, a saber: a formação de professores.

Desta forma, não posso dizer que houve um único momento de análise das informações reunidas através dos questionários, das entrevistas e do grupo focal, e através do retorno constante à produção científica e teórica sobre a formação de professores e o seu contexto sócio-histórico, mas sim que esta esteve presente em toda a pesquisa. Este movimento permitiu selecionar as informaçôes consideradas essenciais ao diálogo entre teoria e empiria, a respeito da formação de professores em atuação e, assim, definir as categorias que utilizei na análise final.

O próprio relatório final da pesquisa, a partir dessa compreensão da análise como um movimento interpretativo contínuo e inacabado, se constituiu como um produto final aberto. Isto é, "produto" porque permitiu a compreensão a respeito do fenômeno estudado, e "aberto" porque essa compreensão não é a única. Tal postura impóe ao pesquisador a necessidade de manter-se atento ao exame detalhado acerca das informaçóes coletadas, procurando entender suas relaçôes com as questóes e os objetivos já definidos para a pesquisa e, a partir desse exercício, avaliar a relevância das informaçôes para o desenvolvimento do estudo. Outro esforço importante é o de enxergar as informaçóes que vão além do previsto e que se constituem em um conhecimento indispensável para que possa se aproximar do fenômeno estudado, pois, como afirma Macedo (2006, p. 209), “O pesquisador postula que a significação real e profunda do material 
analisado reside além do que é expresso. Trata-se de descobrir o sentido velado, em opacidade, das palavras, das frases e das imagens que constituem o material analisado".

\section{Consideraçóes finais}

Um saber que só vê sua finalidade não consegue perceber que tudo o que se quer do final está justamente no meio do caminho (GHEDIN e FRANCO, 2006).

Ao tomar como foco de investigação os processos formativos dos professores da Educação Básica, a pesquisa se inseriu no campo dos estudos que têm ganhado visibilidade entre as pesquisas educacionais e por trazer a necessidade de buscar, no cotidiano desses processos, o conhecimento a respeito de seus protagonistas, das aprendizagens realizadas e de seus desdobramentos na vida dos sujeitos; estudos como esse têm sido fundamentais para construir uma nova lógica a respeito do trabalho docente e do papel do professor na reorganização das relações de trabalho. Sendo assim, ao buscar compreender, de forma contextual e relacional, o movimento formativo dos professores/alunos que frequentaram o curso de formação de professores em atuação, procurei identificar nessa formação as mediaçóes estabelecidas com a experiência desses atores sociais.

A opção metodológica me permitiu uma aproximação maior e mais significativa com os protagonistas sociais e, por conseguinte, as impressôes e implicações com a sua formação. Meu desafio foi captar o movimento formador desses professores/alunos por meio das entrevistas individuais e das sessóes de grupo focal realizadas com o coletivo desses atores sociais. Meu compromisso não foi o de apresentar resultados fechados e, portanto, inquestionáveis. Acredito que os resultados estáo na leitura desses escritos que vamos realizar com nossas implicaçóes e inspiraçôes, mas reconheço que esse 
conhecimento construído por mim, na condição de pesquisadora, constituiu-se em um produto aberto, cujo legado está no compromisso político e ético de apresentar os resultados encontrados com as implicaçóes e limitaçóes inerentes de quem os interpreta.

Nos estudos que realizei sobre formação, ficou clara a necessidade de pensar a formação de professores a partir de um conceito mais amplo desse termo. Foi possível perceber que o movimento formativo vivido pelos atores sociais oscilou entre dois conceitos: um mais ampliado, presente nas discussões fomentadas por alguns professores formadores, principalmente os da disciplina Estágio, os quais viam a formação como uma atividade pela qual se busca, com o outro, as condiçôes para que o saber recebido do exterior seja internalizado para ser transformado em um novo saber, chegando a uma nova forma enriquecida, com significado para uma nova atividade. $\mathrm{O}$ outro conceito, velado, entende a formação como a aprendizagem de um conjunto formulado de saberes, tendo em vista a preparação técnica do professor-aluno para a atuação profissional. Percebi, que nesse embate e vivência, os professores-alunos foram (re) elaborando o seu próprio processo formativo.

Durante a realização da pesquisa, os atores sociais vivenciaram momentos significativos em seu processo formativo. Primeiro, no movimento de compreensão do que era a experiência. $\mathrm{O}$ debate ocorrido no grupo focal foi decisivo para que eles, por meio das reflexôes acerca das suas narrativas, fossem se afastando da compreensão inicial da experiência como vivência e percebessem que toda experiência contém uma vivência que escolhemos ou aceitamos como fonte de aprendizagem. Isso implica na interação que o sujeito precisa estabelecer com esse vivido para que se torne uma experiência. À medida que foram desenvolvendo essas reflexões, outras foram se estabelecendo em razão da necessidade de compreender o lugar que a experiência ocupou no processo formativo vivenciado no curso.

Nesse movimento, foi possível perceber, por meio dos depoimentos, que os atores sociais demonstravam um novo olhar a respeito da prática educativa. Eles já traziam para os debates uma 
consciência política e ética em relação ao seu trabalho, uma visão mais crítica acerca dos conhecimentos que estavam trabalhando com seus alunos e verbalizavam as implicaçóes políticas e sociais do seu próprio trabalho. Isso sinalizava a compreensão da prática docente a partir de suas implicaçóes sociais.

Essas, portanto, poderiam ser as conclusóes que arrolaria sobre a pesquisa. Entretanto, penso ser importante defender três ideias fundamentais para a construção do sentido da investigação. Essas, portanto, poderiam ser as conclusóes que arrolaria sobre a pesquisa.

A primeira delas diz respeito ao caráter formativo da pesquisa. Ao finalizar essa investigação, reconheço que os estudos e as mediaçóes realizadas por meio dos dispositivos usados para estabelecer os diálogos com os atores sociais constituíram-se em um espaço político e ético de escuta sensível, o que nos levou a perceber que a dinâmica da pesquisa, em si mesma, constituiu-se um espaço formativo, possibilitando aos atores sociais não apenas a narração dos fatos já vividos, mas também a reflexão a respeito do vivido. Esta postura e dinâmica permitiram que eles (re)elaborassem suas compreensôes sobre a formação. Não apenas aquela construída durante o curso, mas também a vivida no momento atual. Nos encontros, tanto individuais como coletivos, existia a autoria do sujeito, a narração do vivido, sua problematização e impressões estavam ali, ou seja, eles eram protagonistas desta caminhada. Sua voz estava ali e se misturava a outras para se construir uma compreensão a respeito do vivido no curso. Esse processo resultou em uma nova formação para esses atores sociais, tensionando suas experiências.

A segunda ideia que defendo é a de que o alcance da formação não estava propriamente no curso, e sim nas estratégias que, durante o processo formativo, foram se constituindo para assegurar essa formação. As narrativas dos professores-alunos mostraram que as estratégias se forjaram em duas esferas: uma na própria vivência do/e no curso, e outra na dinâmica da vida pessoal e profissional. 
Na primeira delas, a reuniáo, sob um mesmo contexto de uma diversidade de professores-alunos com histórias e experiências diferentes, por si só, já oportunizou uma formação a todos que participavam. Na segunda ideia, a mobilizaçáo das famílias, das escolas, dos professores formadores e dos próprios professores-alunos para assegurar a frequência e o desempenho no curso também gerou novas aprendizagens e novas transformaçóes. Essas estratégias foram geradas pelo curso e esse foi o seu alcance formativo.

Finalmente, a terceira ideia defendida é a de que, apesar do aparente antagonismo existente entre a formação inicial em atuação desejada para impactar na melhoria do desempenho da educação básica e a busca (nessa formação) da compreensão dos processos de aprendizagem dos professores envolvidos, apesar de distintos, são movimentos que se complementam. De acordo com Pineau (2003), toda formação terá sempre a capacidade de transformar em experiência significativa os acontecimentos cotidianos sofridos no horizonte de um projeto pessoal e coletivo. Neste caso, a formação é algo que se processa, é uma atitude ou uma função que se cultiva e pode, eventualmente desenvolver-se.

Reafirmo, assim, a partir das três ideias apresentadas, a intenção deste trabalho: a de se constituir como um registro reflexivo acerca do movimento formativo de homens e mulheres, reconhecendo que o outro, por ser humano, sempre terá o direito à formação. 


\section{Referências}

ARDOINO, José. Abordagem multirreferencial (plural) das situaçóes educativas e formativas. In: BARBOSA, J. G. (org.). Multirreferencialidade nas ciências e na educação. São Carlos: EDUFSCar, 1998.

BENJAMIN, Walter. Obras escolhidas: Magia e técnicas, arte e política. Tradução Sérgio Paulo Rouanet São Paulo: Brasiliense, 1994.

CLIFFORD, James. A experiência etnográfica: antropologia e literatura no século XX. Tradução José Reginaldo Santos Gonçalves Rio de Janeiro: Editora UFRJ, 1998.

COULON. Alain. Etnometodologia e Educação. Tradução Guilherme João de Freitas Teixeira. Petrópolis: Vozes. 1995.

CORREIA, Vasti G. de Paula. Processos de inclusão escolar: um olhar prospectivo e multirreferencial sobre os saberes fazeres de um grupo de educadores. 2006. Dissertação (Mestrado em Educação)- Programa de Pos- Graduação em Educação, Universidade Federal do Espírito Santo, Vitória, 2006.

GARFINKEL, H. Studies in ethnomethodology. In LAPASSADE, G. As microssociologias. Série pesquisa em educação. Brasília: Liber Livro, 2005.

GATTI, Bernadete Angelina. Grupo focal na pesquisa em Ciências Sociais e Humanas. Brasília, DF: Líber Livro Editora, 2005.

GHEDIN, Evandro. FRANCO, Maria Amélia Santoro. Pesquisa em educação: alternativas investigativas com objetos complexos. São Paulo: Edições Loyola, 2006.

LARROSA, Jorge. Notas sobre a experiência e o saber de experiência. Revista Brasileira de Educação, Rio de Janeiro, 2002. Disponível em: http: <//www.anped.org.br/rbe/rbedigital/RBDE19/RBDE19_04_ JORGE_LARROSA_BONDIA.pdf $>$. Acesso em: 5 maio 2010.

MACEDO, Roberto Sidinei. Atos de currículo e autonomia pedagógica: o socioconstrucionismo curricular em perspectiva. Petrópolis: Vozes, 2013. 
MACEDO, Roberto Sidinei. Etnopesquisa implicada: pertencimento, criação de saberes e afirmação. Brasília, DF: Líber Livro Editora, 2012.

Compreender/mediar a formação - o fundante da educação. Brasília, DF: Líber Livro Editora, 2010.

. Um rigor outro sobre a questáo da qualidade na pesquisa qualitativa. Salvador: Edufba, 2009.

. Etnopesquisa Crítica etnopesquisa-formaçáo. Brasília, DF:

Líber Livro Editora, 2006.

. Por uma epistemologia complexa e multirreferencial nos meios educacionais. In: BARBOSA, Joaquim Gonçalves (org). Reflexão em torno da multirreferencialidade. São Carlos: UFS Car, 1999.

MORIN, Edgar. A inteligência da complexidade. $3^{a}$. ed. São Paulo: Peirópolis, 2000.

MORORÓ, Leila Pio. Rede UNEB2000: da euforia ao espanto, as contradiçóes se estabelecem. 2005. Tese (Doutorado em Educação)- Centro de Educação e Ciências Humanas, Universidade Federal de São Carlos SP, São Carlos, 2005.

NAJMANOVICH, Deise. O sujeito encarnado. Rio de Janeiro: DP\&A, 2001.

PINEAU, Gaston. Temporalidades na formaçáo. Tradução Lucia Pereira de Souza. São Paulo: Triom, 2003.

SANTOS, Boaventura de Sousa. A crítica da razáo indolente contra o desperdício da experiência. 7. ed. São Paulo: Cortez Editora, 2008. 